\title{
THE IMPACT OF PANDEMIC ON OUR DAILY LIFE: THE CASE OF THE INDIA
}

\begin{abstract}
We feel lonely from time to time and these feelings of loneliness sometimes have a serious effect on our mental health. However, in this pandemic this feeling of loneliness was a long time scenario. It has been seen that the long-term loneliness is associated with an increased risk of certain mental health problems, including depression, anxiety and increased stress. During this Pandemic we have seen a different situation and a change this change has a serious impact on everyone's life. Due to Covid-19 there was a serious lock down in the country. This lock down has created a feeling of separation and loneliness in the life's of every individual, due to this lockdown all schools, colleges and Universities have been closed and due to this everything was in an online mode. Many students living in the villages in India had to face a lot of network problems and it was a problem for them to do online classes. All the markets and shops were closed and there was also a rise in the prices and the small shops have to face a lot of losses due to this pandemic situation. Hope everyone can get a better life after this pandemic. My work is focused on all over India but especially on Tripura.
\end{abstract}

Keywords: Ioneliness, separation, mental health, feelings, lockdown.

For citation: Gupta D. (2021) The impact of pandemic on our daily life: the case of the India. Science. Culture. Society. Vol. 27. № 4. P. 44-53. DOI: 10.19181/nko.2021.27.4.4

Introduction. Pandemic has rapidly affected our day-to-day life, businesses, disrupted the world trade and movements. Most of the countries have slowed down their manufacturing of the products.-The various industries and sectors are affected by the cause of this disease; these include the pharmaceuticals industry, solar power sector, tourism, Information and electronics industry. This virus creates significant knock-on effects on the daily life of citizens, as well as about the global economy. This pandemic has affected thousands of peoples, who are either sick or are being killed due to the spread of this disease. The most common symptoms of this viral infection are fever, cold, cough, bone pain and breathing problems, and ultimately leading to pneumonia. This, being a new viral disease affecting humans for the first time, at present vaccines is available. Thus, the emphasis is on taking extensive precautions such as extensive hygiene protocol (e.g., regularly washing of hands, avoidance of face-to-face interaction etc.), social distancing, and wearing of masks, and so on. This virus is spreading exponentially region wise. Countries are banning gatherings of people to the spread and break the exponential curve. Many countries are locking their population and enforcing strict quarantine to control the spread of the havoc of this highly communicable disease.

Research methods. The study is qualitative in nature. Both primary and secondary data are collected for the study. Primary data is collected from field through some interaction and telephonic interview. Secondary data has been collected from books, research articles, websites and internet source.

This paper has been reviewed from the secondary data available, as well as some primary data is have been taken by the help of some interaction of different persons 
and telephonic interview, various past journals, research papers, and other useful websites related to Pandemic, problems of young people and old people, physical and mental as well as Suicidal thoughts, due to the Pandemic. My work is based on India but I had focused mainly on my state Tripura, the second largest state in North east India. For conducting this review research, related articles were focused on and keywords like "stress and anxiety", "Physical and mental health", "suicide problems", "youths", and "social and emotional problems" faced due to Pandemic lockdown were used. For identifying articles that focussed on the theme of Pandemic stress and anxiety among Indian people, specific terms like "suicide", "Physical and mental problems", "youths", "social and emotional problems", and other related words were used.

Loneliness due to pandemic. Loneliness is rarely seen in people who interact with people, and people who are active in society have a better overall health compared to those who do not socialize with others. Loneliness defines public health which is most common in people living in large cities and in poor and remote areas. Other risk factors for loneliness include personal circumstances and circumstances, health and disability, and lifestyle changes. High risk of loneliness for women, young people, and people who are dissatisfied with family, who have negative views of old age, have little contact with relatives, who feel burdened by family and friends for support, listen to COVID-19 related news, have a few entertainment resources, and be released [1].

In the lockdown it can be seen make people who are working in other states came to their hometown and its results loss of their jobs. Many young people have become unemployed due to this and this is one of the very crucial factors for them to get effected due to the lock down.

When a person stays alone in their home for few weeks they probably feel sick and this is not to be regarded as a physical sickness but as a mental sickness, mental health of a person is also an important factor for the lockdown loneliness. Due to this Pandemic many people are feeling the problem of stress and anxiety.

This pandemic has shown different problems, the problem which has given rise to stress and depression for several teenagers. A 1986 study in High Schools in Minnesota, within the US showed that although $61 \%$ of the students are depressed and appear to not handle their problems in constructive ways, $39 \%$ suffer from mild to severe depression [1]. Stress is characterized by feelings of tension, frustration, worry, sadness and withdrawal that commonly last from some hours to some days. Depression is both more severe and longer lasting. Due to this pandemic these problems of stress and depression have been seen in young and old people.

Young people become stressed for several reasons the foremost common of those are: break up with boy/girl friend, increased arguments with parents, trouble with brother or sister, increased arguments between parents, change in parents' financial status, serious illness or injury of friend and trouble with classmates. Additionally, children from single parents or broken homes are subjected to a near harrowing experience which brings about stress and depression. These stress inducing events are centred within the two most vital domains of a teenager's life: home and faculty. In this pandemic many young people have committed suicides there was many reports on suicide, this suicides had been committed due to some personal issues as well as some family problems. This pandemic has shown a different face in everyone's life [2]. 
They relate to problems with conflict and loss. Loss can reflect the important or perceived loss of something concrete like an admirer or money, and it can mean the loss of such intrinsic things as self-worth, respect, friendship or love. Teenagers reply to stress and depression by exhibiting rather more anger and ventilation; being passive and aggressive. They argue, fight and complain nearly everything as it has been seen during the lock down for not doing online classes due to the lack of availability of Smartphone one student from the village of India committed suicide. Drinking, smoking and crying more often - especially in young people - are other popular signs due to staying at home for a long time it became more tremendous. They're also less inclined to try and do things with their family or to travel together with parents' rules and requests. Ultimately, most teens will develop and assume the responsibility for his/her own protection and peace of mind. But during the years of learning and practice, parents, teachers and helping adults must remember of the signs and patterns that signal danger.

Suicide is that the second leading explanation for death in youth aged 1524 years, with a rate of 13.9 deaths by suicide during this population per day; the speed of suicide attempts is 100-200 times more than that of completions 18 [2]. Suicide intention has been much popular in during the lockdown, many people who detached themselves from their family and were living in complete isolation have committed suicide, there are also some reports many movie stars had also committed suicide. During this lockdown young people in danger include people who exhibit declining school grades, chronic sadness, family dysfunction, problems with sexual orientation, individuality, physical or sexual assault, alcohol or drug misuse, have a case history of suicide, or have made a previous suicide attempts.

Several studies have proved that feelings of depression and hopelessness are significantly inducing suicidal thoughts and behaviours. Studies further state that the deadly combination between despair and depression seems to have predicted suicide [3, p. 125].

Impact of Pandemic on Rural India. The social life of man has undergone different stages of development. The earliest human communities were perhaps the loosely organised aggregations of a few families who carried on mutual independent activities in gathering food and defending themselves against their enemies. These primitives' bands were migratory, gradually, man acquired skill and knowledge in agriculture then began the settled life of man. With the development of agriculture and the consequent stabilisation of the source of the food, human communities become more prominent. These communities came to know as village communities. The village is the oldest communities of man.

There are various programs for the development of the villages in India such as Community development programme, Employment development schemes, small farmers Development agency, scheme for providing self - employment to educated unemployed etc. This works are not to be properly functionalised due to the Pandemic.

It has been observed that the urban population is steadily increasing in India. One of the main reasons for this is the migration of rural population towards the urban areas. It has been estimated that around $45 \%$ of the annual increase in urban population is due to migration [4, p. 450].

Before the pandemic it has been seen that many people from outside state has been migrated to the cities for jobs. Employment is the main focus for the people to migrate from one place to another or from the rural areas to the cities but, at the 
present situation it has been seen that many labours from different parts of India visited the north eastern states of India but due the situation of the pandemic there are no jobs available for them and they have to return to their home town but due to unavailability of transportation it was not possible for them to go to their own places , and there was a complete chaos and a problematic situation.

Rural society is based predominantly on agriculture. Village agriculture is sharply distinguished from urban industry by the fact that it is based on direct extraction form Nature by man. Land is the basic means of production in the countryside. Land is a part of nature, through made arable by human labour. From land, the rural people produce, by means of techniques and their labour power, such a variety of agrarian products as food, cotton, jute, tea coffee, tobacco and others. Urban industry only transforms the products of agriculture into industrial products. In city factories and mills, such agricultural products as cotton, jute and sugarcane are transformed into cotton and jute cloth and sugar respectively [5, p. 23].

The basic difference between agriculture and industry plays a significant role in shaping the social institutions, the psychology and the ideology if the rural and urban populations [5, p. 23].

Due to the pandemic situation the small industries are not able to perform in a smooth way, the production was very less and due to the lockdown situation, the farmers are not been able to visit the cities to sell their produce and after the lockdown scenario we can see there is a rise in price of the vegetables in the markets, huge loss in the small shops due to no sell of products.

Role of Government in the Pandemic. The first reason why government is needed for a society is to safeguard and protect the rights of its members or citizen. People have certain unalienable rights that among these are Life, liberty, and the pursuit of happiness. Government is needed to protect these rights. In the absence of proper government, society would be without and order or discipline. People with brutal power could hold all the rights and resources. Therefore, government is needed to make and implement certain laws and regulations to protect people from ruthless violations of their rights.

The second reason to have a government is purely economic. There are certain goods and services that people need but the private sector entrepreneurs may not come forward to provide these goods and services. For example, police, national defence, roads, electricity and infrastructure. Private entrepreneurs would not provide these services because either it would be hard to make people pay for them [6, p. 7].

India alertly implemented surveillance as early as January 17, even before the primary cases were officially detected. This followed by a series of travel advisories and restrictions, and efforts to repatriate and quarantine Indian nationals getting back from abroad. But low testing rates have always been a significant drawback. When the curfew and lockdown were imposed, only 6,500 samples had been tested nationwide, and also the daily testing capacity in mid-March was just 1,400 samples. Testing capacity has increased in recent weeks - over 1,000 laboratories with daily testing capacity of over 300,000 samples - but testing rates are still low. In line with the FIND database from Flag Day, India tests around 4,100 people per million compared with a world average of over 29,000 tests per million.

During this pandemic the government has imposed lockdown and curfews in different states of the country as a result no one can go out of their home except if there is any emergency situation. People during the lockdown used to stay at their home with their family. There was all over police and law official in different areas 
appointed to check if any out of their home without any reason, if they found any person sitting in the park or in the road side strike actions are taken against him/her and it has also be seen in the news and televisions police are giving heavy beating to the people with stick who were unnecessarily moving around without any reason this action took place specially in Tripura located in the north east India. There are some people who have to go to their offices and also for emergency purposes such as government official who are working as officers, doctors, nurses and bankers have to go to their offices for work. On the other hand the government offices run on a roaster duty that means all the employs will come to work at different times, not all together like shifting duty, so to avoid the crowd and maintain a distance. Mask was compulsory for all if any person who are seen without wearing a mask than action are taken against them and also amount of money is also charged such as Rs 500 etc.

In Tripura many students who were studying or working in outside countries and different parts of India, came to their own place and for that sample were taken from them to check if they were Covid-19 positive or not, if someone is found positive than they were taken to the Covid centres and were given free treatment. The government of Tripura send a message in the television and also in the social media that if a person is doing any job outside Tripura not to visit Tripura now because the condition is very bad and many people are effected with this virus and if any one visit in his/her home they may lose their jobs and now to get a job in Tripura is very hard. So it was better for them to stay where they are now.

In Tripura, during the lockdown the shops were opened for 5 hours and it had been said that if anyone want to go to the market they can visit to the market at a given time from $8 \mathrm{am}$ to $12 \mathrm{pm}$. After that the markets or the vegetables shops will remain closed. It has been seen that there are many people who are poor and cannot buy any things due to their economic problems or the old age people who are living in their house alone; it was not possible on their part to go to the market to buy things. So the government provided them the things or the food items which they needed and there was no problem for the poor people and the old age people. This was also the situation in all the states of North east India. So it has been seen that the government in various state played a crucial role during the Pandemic.

The Tripura government announced an Rs.579-crore relief package, including job creation under "Mahatma Gandhi national rural employment guarantee" and financial assistance, to ease the burden on the poor who are facing hard times during the pandemic. Since people are facing hardships due to the COVID-19 situation, the government has decided to generate jobs worth Rs.332 crore under the Mahatma Gandhi National Rural Employment Act (MGNREGA) in the state [7].

A one-time assistance of Rs.1000 and ration items would also be provided to seven lakh needy families, the chief minister said. While the financial assistance which will be sent through Direct Bank Transfer will cost Rs. 70 crore, an additional Rs 80 crore will be required for providing ration to the poor, he said.

The state government would also provide a social pension of two months in advance to over four lakh beneficiaries, including senior citizens and widows, and Rs 24 crore has been sanctioned for the poor under Tripura Urban Employment Programme (TUEP) in urban areas [7]. The state government has sanctioned Rs. 30 crore from the state budget to ensure healthcare for the tribal's, there is also a plan to upgrade the 150- bed hospital.

The government in Khumulwng district of Tripura has laid the foundation for the installation of a 150 LPM oxygen generation plant. The chief minister, during 
his visit to Khumulwng district, also held a meeting with the newly elected representatives of the District. It has been seen that Tripura was holding the top position in the country in terms of vaccination, as many as $16,27,000$ people had been inoculated the state ${ }^{1}$.

The state government has sent a proposal for another 18 oxygen plants because oxygen is important in the battle against COVID-19. Meanwhile, given the surge in corona virus cases in the state, the Tripura government has decided to suspend local train services from May 27 till June 6 2021. However, long-distance trains will continue, as usual, a railway ${ }^{2}$.

Effect on our health. Pandemic also have a serious effect on our health. It is due to loneliness it is a major public health problem because it is associated with an increase in morbidity and mortality. Loneliness is one of the most important challenges to be addressed during the pandemic. The condition can be explained because loneliness levels may increase due to an increase in the number of social and psychiatric disorders after illness. Royal evidence shows that isolation during a Pandemic can results to some infectious diseases, such as fear, frustration, helplessness, isolation, loneliness, shock, sadness and anxiety, and little happiness.

COVID-19 lockdown has led to depression related to length of separation, fear of infection, anxiety, feeling powerless, frustration, boredom, inadequate purchasing, insufficient information, financial loss and discrimination, which further increases social isolation and loneliness.

It have also been seen that, the issue of growing stress is rising in a person. Mental health is deteriorating from house to house while in Corona's custody. Doctors say that the heart crisis has also increased due to this. Mental health is directly related to heart disease and various types of heart problems. That's according to a study by the American Heart Association.

Increased stress increases the secretion of the hormone adrenaline in the body. Its effect is to increase blood pressure. Excessive blood pressure increases the risk of heart disease. Those who have excessive stress on their minds never get relief. As a result, the level of adrenaline in the body is higher all the time. That is the damage to the heart. In addition to this, the secretion of cortical hormone also increases. Psychiatrist Sanjay Grog reports that excessive levels of cortical increase blood cholesterol and sugar levels. It also damages the heart. Inflammation is also caused by stress. It also affects the health of the heart.

Impact on education. The significance of education in modern societies cannot be underestimated. A literate and educated people are very much essential for both to maintain and developing these societies. The crucial need of education for the people in various spheres of modern social life has been highly recognized.

In this pandemic we have noticed a different system of education, online method of learning has been introduced, it is quite interesting and it became very much popular. Actually it has been seen that the Whatsapp apps is mostly used for sending messages or link to the students to join the online classes and meeting apps such as Zoom and Goggle meet were also used for doing the classes in the Universities and

1 Tripura Chief Minister announces Rs 579 crore relief package for pandemic-hit poor people // The Economic Times. May 27, 2021. URL: https://economictimes.indiatimes.com/news/india/tripura-chiefminister-announces-rs-579-crore-relief-package-for-pandemic-hit-poor-people/articleshow/83005510.cms (last request 11.11.2021).

2 Ibid. 
also in different institutions. Online seminars and conferences were also conducted by the use of this meeting apps and it became a very popular platform and an opportunity to present research papers.

Students can sit at their home and can listen the lectures of their teachers not so much hurry to go to Universities and colleges, it was an advantage for them. On the other hand students who are living in the villages have to face many network errors and cannot do their classes properly. Many exams in the school, colleges and Universities were cancelled or taken in an online mode, and it has been seen in Tripura that this system of online examination has gained much popularity.

In Tripura (a small state in the North east India), it has been seen many a families due to its financial problems cannot buy smart phones for their children and due to this situation it is not possible for the children to do their online classes and for that reason some have committed suicide.

So this condition cannot be allowed to continue longer. However, with time the situation is changing, many schools and colleges are going to open. Students feel comfortable in there known positions. So education will progress and people will be benefited.

\section{Social and economic Problems}

Social

a. Service sector is not being able to provide their proper service.

b. Cancellation of sports and tournaments.

c. Cancellation and avoiding of national and international travels.

d. Disruption of celebration of cultural, religious and festive events.

e. Limitless stress on the population.

f. Social distancing with our peers and family members.

g. Closure of the hotels, restaurants and religious places [7, p 78-79].

Economic

a. Slowing of the manufacturing of essential goods.

b. Disruption of the supply chain of products.

c. Losses in national and international business

d. Poor cash flow in the market [7, p. $78-79]$.

Problems in health care. Challenges in the diagnosis, quarantine and treatment of suspected or confirmed cases are many; there was a high burden on the functioning of the existing medical system. Patients with other diseases and health problems are getting neglected and this disease caused them to suffer more. Overload on doctors and other healthcare professionals, who are at a very high risks. It has also been seen that many doctors have also been affected due to this virus when they directly came in contact with their patients. In the medical shops there is a huge crowd of people and it is not possible to provide high protection to all, so there is a disruption of the medical supply chain.

In Tripura, it has been seen that due to lack of oxygen facilities many Covid 19 patients were in a serious condition and many of them had died.

The Tripura health department has advised the state government to stop entry of outsiders to control the spike in Covid cases. A senior official of the state administration said the Tripura government has been advised several times in the past two weeks to restrict the entry of people coming from outside the state. It was further suggested by the government, people who were coming from outside states have to remain in their home at least for a week as quarantine, but it was seen that those 
who are advised home isolation are not following instructions. Even asymptomatic patients are roaming around ${ }^{3}$.

Tripura has about 2,200 active Covid-19 cases and almost half of them are from Agartala and its surroundings. All district hospitals have been strengthened with Covid treatment infrastructure and sufficient number of Covid care centres across the state has been opened ${ }^{4}$.

Role of Social media during the Pandemic. The growth of social media has been phenomenal over the past decade, the appearance of social media platforms like Facebook, Twitter and Instagram has been helping us in many ways, especially to speak better. In tough times sort of a pandemic, the necessity for social media is inevitable so as to pass the data from one place to a different place during a quick manner. For instance, when a whole lockdown was announced in March 2020, people were unable to come out of the shock for some time and it had been the social media platforms that helped them to an outsized extent in knowing what would function and what wouldn't during the lockdown.

The fact to be noted here is that the people are having the ability to share information regarding the provision of beds, oxygen supply, and vaccine through social media during an outbreak like this. Communication has not been really easy within the past and today many lives are being saved using social media. We are able to witness each day the social media posts by various people explaining their needs and therefore the help done by various celebrities and other good people after seeing those posts, the social media platforms are helping the governments to tackle the pandemic by creating a basic awareness among the people on the disease and its spread. The daily announcements given by the government to wear mask and be safe, are reaching the people faster through social media than the normal means. It enables them to remember of the present situation, to follow the protocols and be able to face the challenges. After we say that the social media is contributing immensely to cut back the distress during a virulent disease, it's also a challenge to cope with the fake information that is being spread on a daily basis with a cruel motive to create people afraid. It's important to create use of the social media effectively and acquire eliminate pain during this pandemic situation [8].

During the lockdown many people were using the platform of social media as a source of entertainment; they used to post their story, poems and pictures in the Face book and instagram. It is true that due to the lockdown all the cultural programmes had been cancelled and postponed, hence social media played a vital role during those days, we can able to see many writers and poets in the social media sites produced due to the pandemic. Many people used the social media for cultural activities, doing recitation of poems, dancing competitions, watching drama, singing song and getting many likes and comments in the social media platform.

It can be seen that due to the use of social media people can express their emotions both positive and negative and can get support from others.

Conclusion. This pandemic situation has brought much negative impact in our lives. Loneliness has been created due to pandemic, no physical contact with one another, no offline meeting etc. All Universities, schools and colleges were closed and everything was in an online mode, but also due to pandemic we came to meet

3 Bhattacharjee B. (2021) Prevent entry of outsiders: Tripura health department to government // The Times of India. May 9, 2021. URL: https://timesofindia.indiatimes.com/city/agartala/prevent-entry-ofoutsiders-tripura-health-department-to-government/articleshow/82496144.cms (last request 11.11.2021).

4 Ibid. 
many people in the social media. Social media had also played a very crucial role during the Pandemic. Online seminar and conferences was only possible due to the pandemic.

The main problem in the present day situation is not only Covid 19 as a disease. The more important factor is loneliness psychological depression and separation from each other. Though this factors are essential to prevent the disease till it remains a very important factor in human relationship. Still there is hope and people will come over this situation soon all over the world scientists are labouring hard to produce medicines. So the situation is changed definitely and we have already seen the impact of these changes in the medical world.

\section{References:}

1. Shah S. G. S., Nogueras D., van Woerden H. C., Kiparoglou V. (2020) The COVID-19 Pandemic: A Pandemic of Lockdown Loneliness and the Role of Digital Technology. Journal of Medical Internet Research. Vol. 22. No. 11. DOI: 10.2196/22287.

2. How to help children and teens manage their stress (2019, October 24). American Psychological Association. URL: http://www.apa.org/topics/child-development/stress (last request 11.11.2021).

3. Bhattacharjee A., Ghosh T. (2020) Suicide among youths - Identifying ricks and protection factors: A review analysis. Saraswat: the Tripura University Research Journal. Vol. 1. Issue 1. Pp. 114-130.

4. Shankar Rao C. N. (2004) Sociology of Indian Society. New Delhi : S. Chand Publ. 763 p. ISBN 978-81-2192-403-0.

5. Desai A. R. (1997) Rural Sociology in India. Bombay : Popular Prakashan. 968 p. ISBN 978-81-7154-154-6.

6. Sarma J. V. M. (2018) Public Finance Principles and Practices. New Delhi : Oxford University Press. 363 p. ISBN 978-0-19-947961-0.

7. Haleem A., Javaid M., Vaishya R. (2020) Effects of COVID-19 Pandemic in Daily Life. Current Medicine Research and Practice. Vol. 10. Issue 2. Pp. 78-79. DOI: 10.1016/j. cmrp.2020.03.011.

8. Important role of social media during Pandemic disaster (2021, May 4). Karpagam Academy of higher education. URL: https://kahedu.edu.in/important-role-of-social-mediaduring-pandemic-disaster (last request 11.11.2021).

The article was submitted on November 03, 2021. Accepted on November 20, 2021.

\section{Information about the authors}

Debajyoti Gupta, Masters Student, Department of Liberal Arts. Tripura University. Agartala, India. e-mail: debajyoti111.gupta@gmail.com 


\author{
Д. Гупта ${ }^{1}$ \\ 1 Университет Трипуры. Агартала, Индия.
}

\title{
ВЛИЯНИЕ ПАНДЕМИИ НА ПОВСЕДНЕВНОСТЬ: НА ПРИМЕРЕ ИНДИИ
}

Аннотация. Время от времени все мы чувствуем себя одинокими, и чувство одиночества в определённых ситуациях способно серьезно повлиять на наше психическое здоровье. В период пандемии коронавируса одиночество и отсутствие социальных контактов для многих стало слишком продолжительным, концентрированным. Эксперты отмечают, что длительное одиночество связано с повышенным риском для психического здоровья, оно способствует развитию депрессий, повышению тревожности и стрессу. Во время этой пандемии мы наблюдали и другие факторы, оказавшие не менее серьезное влияние на жизнь и психическое состояние каждого человека. Из-за Covid-19 страна пережила серьезный локдаун. Продолжительный режим ограничений вызвал ощущения отчуждения и одиночества в жизни каждого; в связи с локдауном были закрыты школы, колледжи и университеты; все учебные, рабочие и бытовые процессы перешли в онлайн-режим. Многие студенты, проживающие в деревнях Индии, вынужденно столкнулись с проблемами доступности интернета, что создавало сложности для их участия в дистанционном онлайн-обучении. Все рынки и магазины были закрыты, зафиксирован рост цен, предприятия малого бизнеса и небольшие магазины понесли серьезные убытки из-за этой пандемической ситуации. Остаётся только надеяться на возможность улучшения условий жизни после окончательной победы над коронавирусом. Статья сосредоточена на рассмотрении ситуации в Индии, в первую очередь на положении штата Трипура.

Ключевые слова: одиночество, сепарация, психическое здоровье, чувства, локдаун.

Для цитирования: Гупта Д. Влияние пандемии на повседневность: на примере Индии // Наука. Культура. Общество. 2021. Том 27, № 4. C. 44-53. DOI: 10.19181/nko.2021.27.4.4

Дата поступления в редакцию: 03.11.2021.

Принята к печати: 20.11.2021.

\section{Сведения об авторе:}

Дебайоти Гупта, аспирант, отделение гуманитарных наук.

Университет Трипуры. Агартала, Индия. e-mail: debajyoti111.gupta@gmail.com 